\title{
Infrared and Thermal Analysis of Vanadyl(II) Barbiturate Complex
} Samy M. El-Megharbel ${ }^{\mathrm{a}, \mathrm{b}}$ and Moamen S. Refat ${ }^{\mathrm{b}^{*}, \mathrm{c}}$

Department of Chemistry, Faculty of Science, Zagazig University, Zagazig, Egypt

Samyelmegharbel@yahoo.com

$\mathrm{b}$

Department of Chemistry, Faculty of Science, Taif University, 888 Taif, Saudi Arabia

${ }^{\mathrm{C}}$ Chemistry Department, Faculty of Science, Port Said University, Port Said, Egypt msrefat@yahoo.com

*Corresponding author: E-mail address: Moamen S. Refat <msrefat@yahoo.com>

\section{Abstract}

An usual method for the preparation of vanadyl(II) barbiturate complex was performed under the chemical reaction of vanadyl(II) sulfate with barbituric acid $\left(\mathrm{H}_{2} \mathrm{~L}\right)$ and formulated as: $\left[\mathrm{VO}(\mathrm{HL})_{2}\right] \cdot 2 \mathrm{H}_{2} \mathrm{O}$. This new barbiturate complex was synthesis and characterized by elemental analysis, molar conductivity, magnetic measurements, infrared spectral method and simultaneous thermal analysis (TG/DTG) techniques. The molar conductance measurements proved that barbiturate vanadyl(II) complex is non-electrolytes. The infrared spectra of the barbituric and vanadyl(II) complex are used to identify the mode of coordination. Kinetic and thermodynamic parameters $\left(E^{*}, \Delta H^{*}, \Delta S^{*}\right.$ and $\left.\Delta G^{*}\right)$ of $\mathrm{H}_{2} \mathrm{~L}$ ligand and its complex are estimated according to the DTG curves.

Keywords: Barbituric acid; vanadyl(II) sulfate, infrared spectra; thermal analyses, thermodynamic parameters

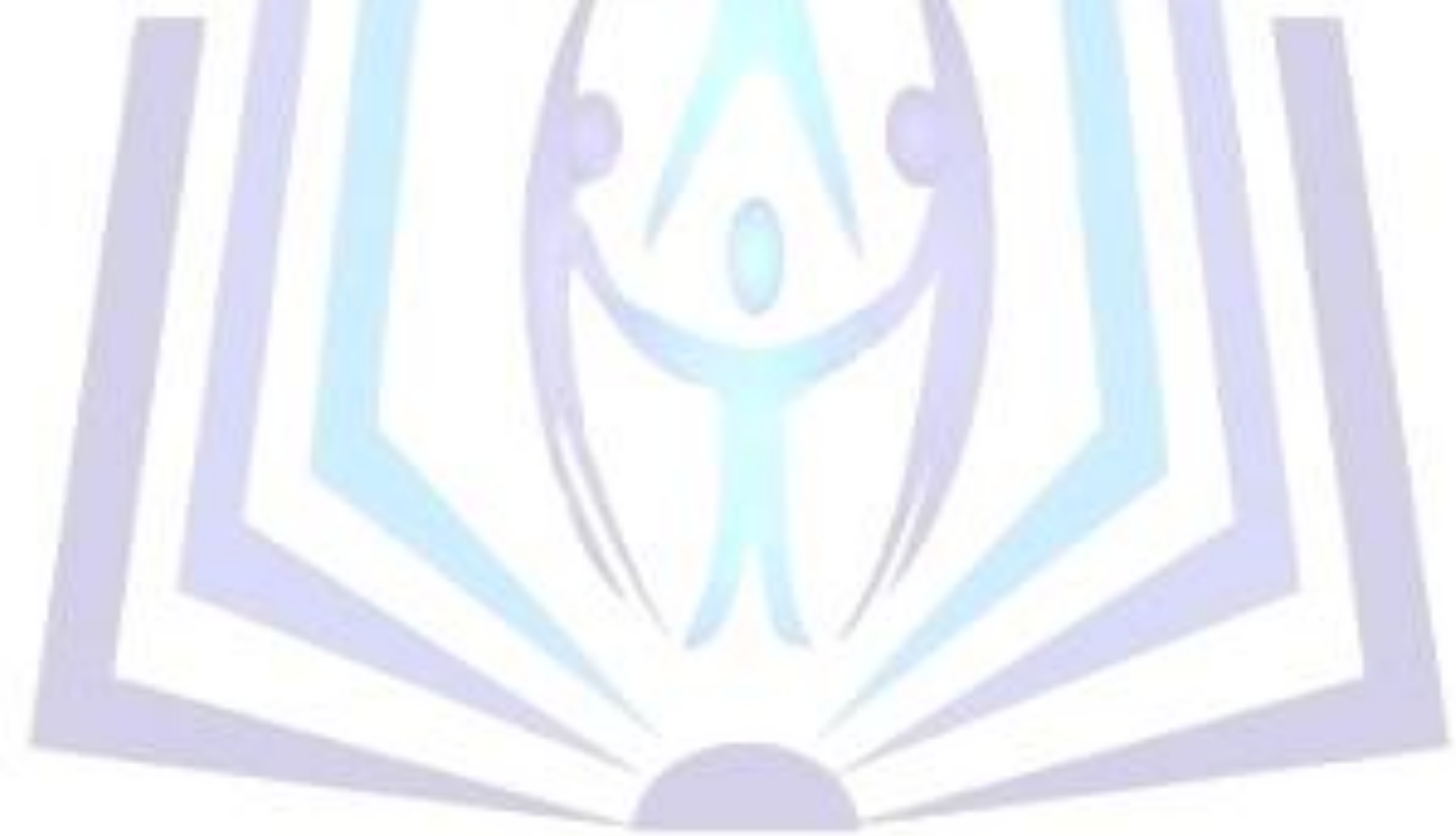

\section{Council for Innovative Research}

Peer Review Research Publishing System

\section{Journal: Journal of Advances in Chemistry}

\author{
Vol. 5, No. 2 \\ editor@cirworld.com \\ www.cirworld.com, member.cirworld.com
}




\section{1- Introduction}

The compounds containing pyrimidine ring play an important role in many biological systems [1], where they exist in nucleic acids, several vitamins, coenzymes and antibiotics. These provide potential binding sites for metal ions, and any information on their coordinating properties is important as a means of understanding the role of the metal ions in biological systems. Many compounds which have therapeutic importance containing the pyrimidine ring system. Pyrimidine compounds are also used as hypnotic drugs for the nervous system [2, 3]. Barbiturates are a class of drugs that are utilized as anesthetics and sleeping agents and are used for the treatment of anxiety, epilepsy and other psychiatric disorders, and possess effects on the motor and sensory functions $[4,5]$. Compounds containing nitrogen and sulphur as donor atoms like thiouracil, have an important role to be use as anti-cancer and anti-viral activities [6]. Barbiturates are malonylurea derivatives with different substituent's in the C-5 position [7-22]. Barbiturates and their derivatives are widely used as sedative hypnotic drugs under a variety of conditions and are also employed for anesthesia [23]. For example, phenytoin, one of the cyclic ureides related in structure to the Barbiturate, was reported to be the least hypnotic, most strongly anticonvulsant and most effective against grand mal [23]. Barbituric acid $(2,4,6(1 \mathrm{H}, 3 \mathrm{H}, 5 \mathrm{H})$-pyrimidinetrione) is used in the manufacture of plastics and pharmaceuticals [24]. 2-Thiobarbituric acid is also used in the 2-thioxo-2,3-dihydro-4,6 $(1 \mathrm{H}, 5 \mathrm{H})$-pyrimidinedione pharmacological and analytical fields [25-30]. Furthermore, it has been suggested that the presence of metal ions in biological fluids, could have a significant effect on the therapeutic action of drugs [31,32]. Many diverse applications of metal species are aimed at understanding the natural roles of metal ions, or at exploiting the unique properties of metal centers in the study of the biology or biochemistry of nucleic acid and nucleic-acid constituents [33]. Synthesis of barbituric and thiobarbituric acid complexes derived from cobalt(II), nickel(II) and copper(II) salts were carried out [34]. The complexes of 2-thiobarbituric acid with Fe(II), Fe(III), Co(II), $\mathrm{Cu}(\mathrm{II}), \mathrm{Zn}(\mathrm{II})$ and $\mathrm{Cd}(\mathrm{II})$ have been isolated and characterized by Gehad et al [35]. Herein, the present investigation was undertaken to study the course of the interaction between barbituric acid and vanadyl(II) sulfate salt. The thermal stabilities and the kinetic and thermodynamic parameters data were calculated.

\section{Experimental}

\subsection{Materials and instrumentations}

All chemicals were reagent grade and used without further purification. Barbituric acid was purchased from Fluka Chemical Co., and the $\mathrm{VOSO}_{4} \cdot \mathrm{XH}_{2} \mathrm{O}$ was purchased from (Aldrich Co.). Carbon, hydrogen and nitrogen contents were determined using a Perkin-Elmer $\mathrm{CHN}$ 2400. The vanadium metal content was found gravimetrically by converting the compounds into their corresponding oxide. IR spectra were recorded on Bruker FT-IR Spectrophotometer $\left(4000-400 \mathrm{~cm}^{-1}\right)$ in $\mathrm{KBr}$ pellets. Molar conductivities of freshly prepared $1.0 \times 10^{-3} \mathrm{M}$ DMSO solutions were measured using Jenway 4010 conductivity meter. Magnetic measurements were carried out on a Sherwood Scientific magnetic balance using Gouy method which, calibrated as: two very good solid calibrants are used; $\mathrm{Hg}\left[\mathrm{Co}(\mathrm{CNS})_{4}\right]$ and $\left[\mathrm{Ni}(\mathrm{en})_{3}\right]\left(\mathrm{S}_{2} \mathrm{O}_{3}\right)$. They are easily prepared pure, do not decompose or absorb moisture and pack well. Their susceptibilities at $20^{\circ} \mathrm{C}$ are $16.44 \times 10^{-6}$ and $11.03 \times 10^{-6}$ C.g.s. Units, decreasing by $0.05 \times 10^{-6}$ and $0.04 \times 10^{-6}$ per degree temperature raise respectively, near room temperature. The cobalt compound, besides having the higher susceptibility, also packs rather densely and is suitable for calibrating low fields, while the nickel compound with lower susceptibility and density is suitable for higher field [36]. Here we are used $\mathrm{Hg}\left[\mathrm{Co}(\mathrm{CNS})_{4}\right]$ only as calibrant. Thermo gravimetric analysis (TG/DTG) was carried out in dynamic nitrogen atmosphere $(30 \mathrm{ml} / \mathrm{min}) \mathrm{with}$ a heating rate of $10^{\circ} \mathrm{C} / \mathrm{min}$ using a Schimadzu TGA-50H thermal analyzer.

\subsection{Synthesis of vanadyI(II) barbiturate complex}

A general method for the preparation as follows: the vanadyl(II) sulfate hydrate was dissolved in $20 \mathrm{ml}$ of methanol and then added slowly to $25 \mathrm{ml}$ of methanolic solution of free barbituric acid under magnetic stirring. The $\mathrm{pH}$ of each mixture was neutralized at $\mathrm{pH} 7.0$ using $0.1 \mathrm{M}$ methanolic sodium hydroxide solution. The obtained precipitate was filtered off then washed several times with hot methanol and then dried under vacuum at $60{ }^{\circ} \mathrm{C}$. Mwt $361.16 \mathrm{~g} / \mathrm{mol}$, Yield $84 \%$, m.p: $>300$. Anal.: Calculated for $\mathrm{C}_{8} \mathrm{H}_{14} \mathrm{~N}_{4} \mathrm{O}$ V: $\mathrm{C}, 26.60 ; \mathrm{H}, 3.91 ; \mathrm{N}, 15.51$; V, 14.10. Found: C, 26.43; H, 3.62; N, 15.07; V, 13.67 .

\section{3- Results and discussion}

Barbituric acid is one of the common alterdentate ligands which offers to a metal ion more than one equivalent coordination site. In an alterdentate ligand there is, principally, always a rearrangement possible in which the metal is transferred from one site to another one. This can be either an intermolecular or intramolecular process. The rearrangement reaction is kinetically controlled by the activation energy and entropy experienced by the metal on the reaction path. The free energy difference is zero by definition, if the coordination sites are equivalent [37, 38]. We can consider the barbituric acid and 2-thiobarbituric acid are alterdentate ligands because they have more than one equivalent coordination site as shown in Scheme 1. 


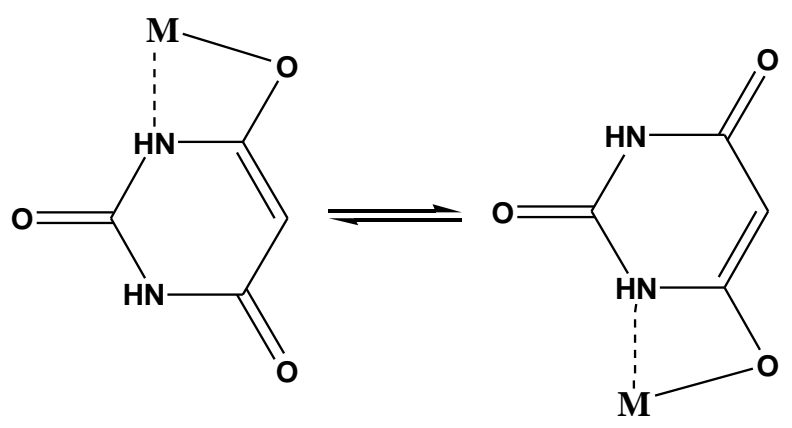

Scheme 1: The possible chelation pathways of barbituric acid metal complex

The results of the elemental analysis and some physical characteristics of the obtained vanadyl(II) barbiturate are agreement with 1:2 molar ratio of vanadyl(II) ions to barbituric acid. This complex is air-stable, hygroscopic, higher melting point above $300{ }^{\circ} \mathrm{C}$, insoluble in $\mathrm{H}_{2} \mathrm{O}$ and most of organic solvents except for DMSO and DMF.

\subsection{Molar conductivities}

The molar conductivity values for the barbituric acid and vanadyl(II) barbiturate complex in DMSO solvent $\left(1.0 \times 10^{-3}\right.$ M) were in the range 15 and $30 \Omega^{-1} \mathrm{~cm}^{2} \mathrm{~mol}^{-1}$, respectively, this measurement in the range suggesting them to be nonelectrolytes nature. Conductivity measurements have frequently been used in structural of metal chelates (mode of coordination) within the limits of their solubility. They provide a method of testing the degree of ionization of the complexes, the molecular ions that a complex liberates in solution (incase of presence anions outside the coordination sphere), the higher will be its molar conductivity and vice versa [39]. These results were strongly supported with the chemical analysis (elemental analysis data) where $\mathrm{Cl}^{-}$ions are not detected by addition of $\mathrm{AgNO}_{3}$ solution, this tested well matched with $\mathrm{CHN}$ data.

\subsection{Infrared spectra}

The main IR data of barbituric acid $\left(\mathrm{H}_{2} \mathrm{~L}\right)$ and its vanadyl(II) complexes are summarized in Table 1 and shown in Fig.1. The IR spectrum of barbituric acid exhibits an intense band due to the carbonyl vibrations: it has poorly defined maxima at 1766,1720 and $1696 \mathrm{~cm}^{-1}$. Previously $[40,41]$, the band at $1766 \mathrm{~cm}^{-1}$ was assigned to the vibrations of the carbonyl group in the amide fragment (-NH-CO-NH-) and the bands at $1720 \mathrm{~cm}^{-1}$ and $1696 \mathrm{~cm}^{-1}$ can be attributed to vibrations of the two ketone groups in positions C4 and C6, respectively. In the infrared spectrum of the vanadyl(II) complex, the absorption band of carbonyl group in position C2 at $\sim 1760 \mathrm{~cm}^{-1}$ was lower shifted to appear at range 1700-1690 $\mathrm{cm}^{-1}$, while the absorption intensity in the range of $1641-1601 \mathrm{~cm}^{-1}$ noticeably increases. This proves that the chelation occurs through the involvement of the carbonyl group in position $\mathrm{C} 4$ or $\mathrm{C} 6$ and the nearest $\mathrm{NH}$ group. The stretching broad band vibration of $\mathrm{OH}^{-}$group $v\left(\mathrm{O}-\mathrm{H}^{-}\right)$ is occurred as expected [42] at the range $~ 3390 \mathrm{~cm}^{-1}$. The appearance of a weak band at $500-400 \mathrm{~cm}^{-1}$ provides a strong evidence for the formation of $\mathrm{M}-\mathrm{O}$ and $\mathrm{M}-\mathrm{N}$ bond $[43,44]$. The characteristic $\mathrm{v}(\mathrm{V}=\mathrm{O})$ of oxovanadium(IV) complex appears as a medium-strong band at $1071 \mathrm{~cm}^{-1}$ in the IR spectrum, in agreement with the literature [43].

\subsection{Magnetic Measurements}

Magnetic measurements were carried out on a Sherwood Scientific magnetic balance according to the Gauy method. The calculations were evaluated by applying the following equations:

$$
\begin{aligned}
& \chi_{g}=\frac{c l\left(R-R_{o}\right)}{10^{9} M} \\
& \chi_{m}=\chi_{g} M W t . \\
& \mu_{\text {eff }}=2.828 \sqrt{\chi_{m} T}
\end{aligned}
$$

Where; $X$ is mass susceptibility per gm sample

$\mathrm{C}$ is the calibration constant of the instrument and equal to (1.135)

$R$ is the balance reading for the sample and tube

$R_{0}$ is the balance reading for the empty tube 
$M$ is the weight of the sample in gm

$\mathrm{T}$ is the absolute temperature

The magnetic moment of the $\left[\mathrm{VO}(\mathrm{HL})_{2}\right] \cdot 2 \mathrm{H}_{2} \mathrm{O}$ complex at $\mathrm{T}=300 \mathrm{~K}$ was calculated. From the experimental data1.74 B.M., the observed value of the effective magnetic moments $\mu_{\text {eff }}$ operated for the vanadyl(II) complex is convenient with experimental values [45] with square-pyramidal geometry.

\subsection{Thermogravimetric analysis}

Thermal analysis curve (TG) of the studied vanadyl(II) barbiturate complex is shown in Fig. 2 . The thermoanalytical results are summarized in Table 2.

\subsection{Kinetic studies}

In recent years there has been increasing interest in determining the rate-dependent parameters of solid-state nonisothermal decomposition reactions by analysis of TG curves. Several equations [46-53] have been proposed as means of analyzing a TG curve and obtaining values for kinetic parameters. Many authors [46-51] have discussed the advantages of this method over the conventional isothermal method. The rate of a decomposition process can be described as the product of two separate functions of temperature and conversion [47], using

$\mathrm{d \alpha} / \mathrm{dt}=\mathrm{k}(\mathrm{T}) \mathrm{f}(\alpha)$

Where $\alpha$ is the fraction decomposed at time $t, k(T)$ is the temperature dependent function and $f(\alpha)$ is the conversion function dependent on the mechanism of decomposition. It has been established that the temperature dependent function $k(T)$ is of the Arrhenius type and can be considered as the rate constant $\mathrm{k}$.

$k=A e^{-E^{*} / R T}$

where $\mathrm{R}$ is the gas constant in $\left(\mathrm{Jmol}^{-1} \mathrm{~K}^{-1}\right)$. Substituting equation (2) into equation (1), we get, $d \alpha / d T=\left(A / \varphi e^{-E^{*} / R T}\right) f(\alpha)$

where $\varphi$ is the linear heating rate $\mathrm{dT} / \mathrm{dt}$. On integration and approximation, this equation can be obtained in the following form $\ln g(\alpha)=-E^{*} / R T+\ln \left[A R / \varphi E^{*}\right]$

Where $g(\alpha)$ is a function of $\alpha$ dependent on the mechanism of the reaction. The integral on the right hand side is known as temperature integral and has no closed for solution. So, several techniques have been used for the evaluation of temperature integral. Most commonly used methods for this purpose are the differential method of Freeman and Carroll [46] integral method of Coat and Redfern [48], the approximation method of Horowitz and Metzger [51]. In the present investigation, the general thermal behaviors of the vanadyl(II) barbiturate complex in terms of stability ranges, peak temperatures and values of kinetic parameters, are summarized in Table 3. The kinetic parameters have been evaluated using the following methods and the results obtained by these methods are well agreement with each other. The following two methods are discussed in brief.

\section{Coats- Redfern equation:}

The Coats-Redfern equation, which is a typical integral method, can be represented as:

$\int_{0}^{\alpha} \frac{\mathrm{d} \alpha}{(1-\alpha)^{\mathrm{n}}}=\frac{A}{\varphi} \int_{T_{1}}^{T_{2}} \exp \left(-\frac{E^{*}}{R T}\right) \mathrm{d} t$

For convenience of integration the lower limit $T_{1}$ is usually taken as zero. This equation on integration gives;

$$
\ln \left[-\frac{\ln (1-\alpha)}{T^{2}}\right]=-\frac{E^{*}}{R T}+\ln \left[\frac{A R}{\varphi E^{*}}\right]
$$

A plot of left-hand side (LHS) against $1 / T$ was drawn. $E^{*}$ is the energy of activation in $\mathrm{J} \mathrm{mol}^{-1}$ and calculated from the slop and $A$ in $\left(\mathrm{s}^{-1}\right)$ from the intercept value. The entropy of activation $\Delta \mathrm{S}^{*}$ in $\left(\mathrm{JK}^{-1} \mathrm{~mol}^{-1}\right)$ was calculated by using the equation:

$\Delta S^{*}=R \ln \left(A h / k_{B} T_{S}\right)$

Where $k_{B}$ is the Boltzmann constant, $h$ is the Plank's constant and $T_{S}$ is the DTG peak temperature [54].

\section{Horowitz-Metzger equation:}

The Horowitz-Metzger equation is an illustrative of the approximation methods. These authors derived the relation:

$$
\log \left[\left\{1-(1-\alpha)^{1-n}\right\} /(1-n)\right]=E^{*} \theta / 2.303 R T_{s}^{2} \quad \text { for } n \neq 1
$$


When $n=1$, the LHS of equation 4 would be $\log [-\log (1-\alpha)]$. For a first-order kinetic process the Horowitz-Metzger equation may be written in the form:

$\log \left[\log \left(w_{\alpha} / w_{Y}\right)\right]=E^{*} \theta / 2.303 R T_{s}^{2}-\log 2.303$

where $\theta=T-T_{s}, w_{y}=w_{\alpha}-w, w_{\alpha}=$ mass loss at the completion of the reaction; $w=$ mass loss up to time $t$. The plot of $\log \left[\log \left(w_{\alpha} / w_{y}\right)\right]$ vs $\theta$ was drawn and found to be linear from the slope of which $E^{*}$ was calculated. The pre-exponential factor, A, was calculated from the equation:

$E^{*} / R T_{s}^{2}=A /\left[\varphi \exp \left(-E^{*} / R T_{s}\right)\right]$

The entropy of activation, $\Delta \mathrm{S}^{*}$, was calculated from equation 3. The enthalpy activation, $\Delta \mathrm{H}^{*}$, and Gibbs free energy, $\Delta \mathrm{G}^{*}$, were calculated from; $\quad \Delta H^{*}=E^{*}-R T$ and $\Delta G^{*}=\Delta H^{*}-T \Delta S^{*}$, respectively.

\subsection{Structure of the barbiturate and 2-thiobarbiturate complexes}

Accordingly, the above mentioned discussions using elemental analysis, magnetic studies, molar conductance, infrared spectra as well as thermogravimetric analysis; the suggested structures of the vanadyl(II) barbiturate complex can be represented in Scheme 2.

\section{References}

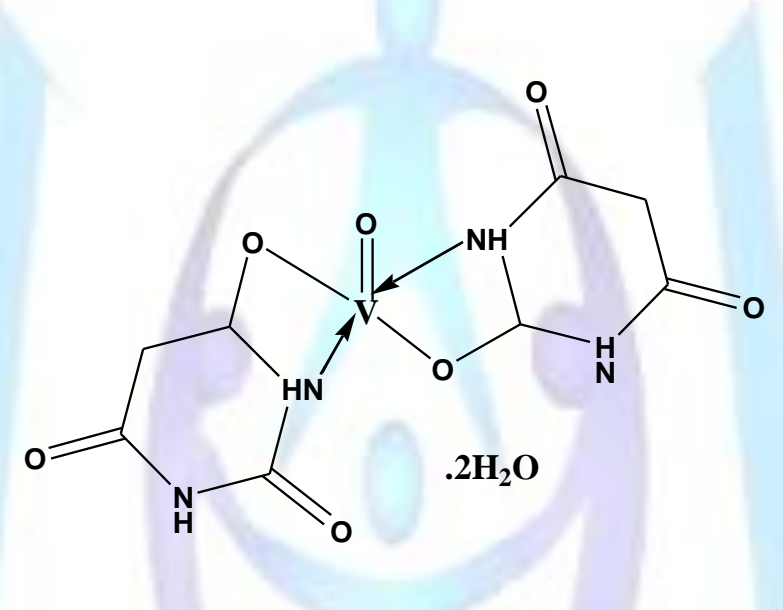

Scheme 2: Suggested structure of vanadyl(II) barbiturate complex

[1] Hueso, F., Illán, N. A., Moreno, M. N., Martínez, J. M. and Ramírez, M. J. 2003 J. Inorg. Biochem, 94, 326.

[2] Armando, C. and Jennifer, B.1996 J. Mass. Spect., 31, 403, C.A.124, 22.

[3] Raman, N., Kulandaisamy, A., Thangaraja, C., Manisankar, P., Viswanathan, S. and Vedhi, C.2004. Trans. Met. Chem., 29, 129.

[4] Fillaut, J. L., de Los Rios, I., Masi, D., Romerosa, A., Zanobini , F.and Peruzzini, M.2002. Eur. J. Inorg. Chem., 935.

[5] Temiz-Arpaci, O., Ozdemir, A., Yalcin, I., Yildiz, I., Aki-Sener, E. and Altanlar, N.2005. Arch., Pharm., $338,105$.

[6] Izatt, R. M., Christensen, J. H. and Rytting, J. H.1971.Chem. Rev., 72, 439.

[7] Cutting, W. C.,1967. Hand Book of Pharmacology, 3rd Edit., Appleton-Century-Crofts, Meredith Publishing Company, New York.

[8] Kazyak, L. and Knoblock, E. C. 1968. Anal. Chem., 35, 1448.

[9] Toth,A.and Billes, F.1968 Acta Chim. Acad. Sci. Hung., 56, 229.

[10] Smyth, W. F., Jenkins, T. S., Sleklera, J. and Baydor, A.1975. Anal. Chim. Acta., 80, 233.

[11] Parker, K. D., Fontan, C. R. and Kirk, P. L.1964. Microchem. J., 8, 28.

[12] Gudzinowicz, B.J. and Clarke, S. J.1963. J. Gas Chrom., 3, 147.

[13] Hansen, E. B. and Svendsen, A.B.1962. J. Pharm. Sci., 51, 318.

[14] Hansen, A. B.1962. J. Pharm. Sci., 51, 494. 
[15] Martin, A. F. and Driscoll, J. L. 1966. Anal. Chem., 38, 345.

[16] Gupta, V. D. 1963. Ind. J, Pharm., 25, 161.

[17] Poethke, W.and Preussler, M.1965.Pharm. Zentralhalle, 104, 464.

[18] Abou-Eittah, R. and Osman, A.1979. J. Inorg. Nucl. Chem., 41, 1079.

[19] Murphy, R. J. and Svehla, G.1978. Anal. Chim. Acta., 99, 115.

[20] Smyth, W. F., Svehla, G. and Zuman, P.1970 Anal. Chim. Acta., 52, 129.

[21] Ivaska, A., Vaneesorn, Y., Davidson, I. D. and Smyth, W. F.1980 Anal. Chim. Acta., 121, 51.

[22] Eichorn, G. L.1973.Inorganic Biochemistry, Vol. 2, Chapters 32 and 33, Elsevier, New York, N.Y.

[23] Delgado, J.N. and Remers, W.A. 1991. J.B. Lippincott (ed) in Wilson and Gisvold's Textbook of Organic Medicinal and Pharmaceutical Chemistry, 9th Edit., Philadephia, pp. 39, 341, 376.

[24] Merck index $13^{\text {th }}$

[25] Sikorska, H.T. Z.,1968. Anal. Chem., 234, 414.

[26] Sikorska, H.T. 1969. Microchim. Acta, 715.

[27] Agarwal, J., Gupta, Y.K., Bhargave, K.P., Shankar, K.1981.Ind. J. Chem. 20B, 417.

[28] Srivastava, V.K., Satsangi, R.K., Shankar, K., Kishor, K.1981. Pharmazie, 36, 252.

[29] Dhasmana, A., Barthal, J.P., Pandey, B.R., Ali, A., Bhargave, K.P., Parmer, S.S. 1981. J. Hetercocycl. Chim., 18, 635.

[30] Morelli, B.1982. Analyst, 107, 282.

[31] Kirschner, S., Wei, Y.K., Francis, D., Bergam, J.G.1966. J. Med. Chem., 9, 396.

[32] Sornson, J.R.J.1978.Prog. Med. Chem., 15, 211.

[33] Sigel, H.1967. Helv. Chem. Acta, 50, 582; H. Sigel, Eur. J. Biochem., 3, 530 (1968); H. Sigel, J. Am. Chem. Soc., 97, 3209 (1975).

[34] Masoud, M.S., Heiba, A.M., Ashmawy, F.M. 1983.Trans. Met. Chem., 8, 124.

[35] Zaki, Z.M. and Mohamed, G.G.2000.Spectrochimica Acta, Part A, 56A(7) 1245.

[36] Burger, K. 1 973“Coordination Chemistry: Experimental Methods”, Butterworth group, Britain.

[37] von Zelewsky, A.1981. Inorg. Chem., 20, 4449.

[38] Daul, C., Deiss, E., Gex, J.N., Perret, D., Schaller, D. and Von Zelewsky,1983. A. J. Am. Chem. Soc., 105(26), 7556.

[39] Refat, M.S. 2007. J. Mol. Struct., under press.

[40] Kovalchukova, O.V., Gridasova, R.K. and Zaitsev, B.E.,1981. Zh. Neorg. Khim., 26(4), 985.

[41] Leon Palomino, M.I., Gridasova, R.K., Zaitsev, B.E. and Kovalchukova, O.V. 1981. Zh. Neorg. Khim., 32(10), 2583.

[42] Gelfand, L.S., laconianni, F.J., Pytlewski, L.L. 1980. A.N. Speca, C.M. Mikulski and N.M. Karayannis, J. Inorg. Nucl. Chem., 42, 377.

[43] Nakamato, K. and Mc Carthy, P. J. 1968."Spectroscopy and Structure of Metal Chelate Compounds", John Wiley, New York, p. 268.

[44] Stefan, S.L., El-Shetary, B.A., Hanna, W.G., El-Maraphy, S.B. 1987. Microchem. J., 35, 51.

[45] Earnshow, A. 1968. "Introduction to Magneto Chemistry", Academic press, New York.

[46] Freeman, E.S. and Carroll, B.1958. J. Phys. Chem., 62, 394.

[47] Sestak, J., Satava, V. and Wendlandt, W.W.1973.Thermochim. Acta, 7, 333 (1973).

[48] Coats, A.W. and Redfern, J.P.1964. Nature, 201, 68.

[49] Ozawa, T.1965.Bull. Chem. Sot. Jpn., 38, 1881.

[50] Wendlandt, W.W.1.974Thermal Methods of Analysis, Wiley, New York. 
[51] Horowitz, H.W. and Metzger, G.1963. Anal. Chem., 35, 1464.

[52] Flynn, J.H. and Wall, L.A. 1966. Polym. Lett., 4, 323.

[53] Kofstad, P.1957. Nature, 179, 1362.

[54] Flynn, J. H. F. and Wall, L. A. 1996. J. Res. Natl. Bur. Stand., 70A, 487.

Table 1: IR frequencies (cm-1) of barbituric acid (H2L) and its vanadyl(II) complex

\begin{tabular}{|c|c|c|}
\hline Assignments & $\left(\mathrm{H}_{2} \mathrm{~L}\right)$ & {$\left[\mathrm{VO}(\mathrm{HL})_{2}\right] \cdot 2 \mathrm{H}_{2} \mathrm{O}$} \\
\hline $\mathrm{v}_{\mathrm{s}}(\mathrm{OH})$ & 3478 & 3395 \\
\hline $\mathrm{v}(\mathrm{NH})$ & 3204 & 3105 \\
\hline $\mathrm{v}(\mathrm{C}=\mathrm{O})$ & $1766,1720,1696$ & $1710,1635,1591$ \\
\hline$\delta(\mathrm{NH})$ & 1424 & 1474 \\
\hline $\mathrm{v}(\mathrm{C}=\mathrm{N})$ & 1349 & 1333 \\
\hline $\mathrm{v}(\mathrm{C}-\mathrm{O})+\delta(\mathrm{O}-\mathrm{H})$ & 1285 & 1262 \\
\hline$v(C-N)$ & 1263 & 1210 \\
\hline $\mathrm{v}(\mathrm{V}=\mathrm{O})$ & 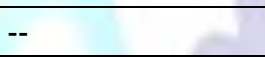 & 1072 \\
\hline$\delta(\mathrm{O}-\mathrm{H})$ & 807 & 843 \\
\hline $\mathrm{v}(\mathrm{M}-\mathrm{O})+\mathrm{v}(\mathrm{M}-\mathrm{N})$ & - & $544,527,415$ \\
\hline
\end{tabular}

Table 2: Thermal data of the vanadyl(II) barbiturate complex

\begin{tabular}{|c|c|c|c|c|c|c|}
\hline \multirow[t]{2}{*}{ Compound } & \multirow[t]{2}{*}{ Steps } & \multirow[t]{2}{*}{$\begin{array}{c}\text { Temp. } \\
\text { range }\left({ }^{\circ} \mathrm{C}\right)\end{array}$} & \multirow{2}{*}{$\begin{array}{l}\text { DTG } \\
\text { peak } \\
\left({ }^{\circ} \mathrm{C}\right)\end{array}$} & \multicolumn{2}{|c|}{$\begin{array}{c}\mathrm{TG} \\
\text { Weight loss (\%) }\end{array}$} & \multirow[t]{2}{*}{ Assignments } \\
\hline & & & & Calc. & Found & \\
\hline$\left[\mathrm{VO}(\mathrm{HL})_{2}\right] \cdot 2 \mathrm{H}_{2} \mathrm{O}$ & $\begin{array}{l}1^{\text {st }} \\
2^{\text {nd }}\end{array}$ & $\begin{array}{l}200-300 \\
300-800\end{array}$ & $\begin{array}{l}250 \\
440\end{array}$ & $\begin{array}{l}9.96 \\
64.79 \\
25.25\end{array}$ & $\begin{array}{l}10.00 \\
64.22 \\
24.86\end{array}$ & $\begin{array}{l}2 \mathrm{H}_{2} \mathrm{O} \\
\mathrm{C}_{8} \mathrm{H}_{10} \mathrm{~N}_{4} \mathrm{O}_{4.5} \\
\mathrm{VO}_{2.5}+\mathrm{C} \text { (residue) }\end{array}$ \\
\hline
\end{tabular}

Table 3: Kinetic parameters using the Coats-Redfern (CR) and Horowitz-Metzger (HM) operated for the vanadyl(II) barbiturate complex

\begin{tabular}{|c|c|c|c|c|c|c|c|c|}
\hline \multirow[t]{2}{*}{ complex } & \multirow[t]{2}{*}{ stage } & \multirow[t]{2}{*}{ method } & \multicolumn{5}{|c|}{ parameter } & \multirow[t]{2}{*}{$r$} \\
\hline & & & $\begin{array}{l}E \\
\left(\mathrm{~kJ} \mathrm{~mol}^{-1}\right)\end{array}$ & $A\left(\mathrm{~s}^{-1}\right)$ & $\begin{array}{l}\Delta S \\
\left(\mathrm{~J} \mathrm{~mol}^{-1} \mathrm{~K}^{-1}\right)\end{array}$ & $\begin{array}{l}\Delta H \\
\left(\mathrm{~kJ} \mathrm{~mol}^{-1}\right)\end{array}$ & $\begin{array}{l}\Delta G \\
\left(\mathrm{~kJ} \mathrm{~mol}^{-1}\right)\end{array}$ & \\
\hline \multirow[t]{2}{*}{$\mathrm{VO}(\mathrm{II})$} & $1^{\text {st }}$ & $\begin{array}{l}\text { CR } \\
\mathrm{HM}\end{array}$ & $\begin{array}{l}44 \\
50\end{array}$ & $\begin{array}{l}9.57 \times 10^{4} \\
2.19 \times 10^{6}\end{array}$ & $\begin{array}{l}-150 \\
-125 \\
\end{array}$ & $\begin{array}{l}48 \\
50\end{array}$ & $\begin{array}{l}41 \\
47 \\
\end{array}$ & $\begin{array}{l}0.9947 \\
0.9977 \\
\end{array}$ \\
\hline & $2^{\text {nd }}$ & $\begin{array}{l}\mathrm{CR} \\
\mathrm{HM}\end{array}$ & $\begin{array}{l}72 \\
70 \\
\end{array}$ & $\begin{array}{l}3.20 \times 10^{1} \\
2.18 \times 10^{7}\end{array}$ & $\begin{array}{l}-104 \\
-107 \\
\end{array}$ & $\begin{array}{l}250 \\
245 \\
\end{array}$ & $\begin{array}{l}69 \\
67 \\
\end{array}$ & $\begin{array}{l}0.9951 \\
0.9953 \\
\end{array}$ \\
\hline
\end{tabular}




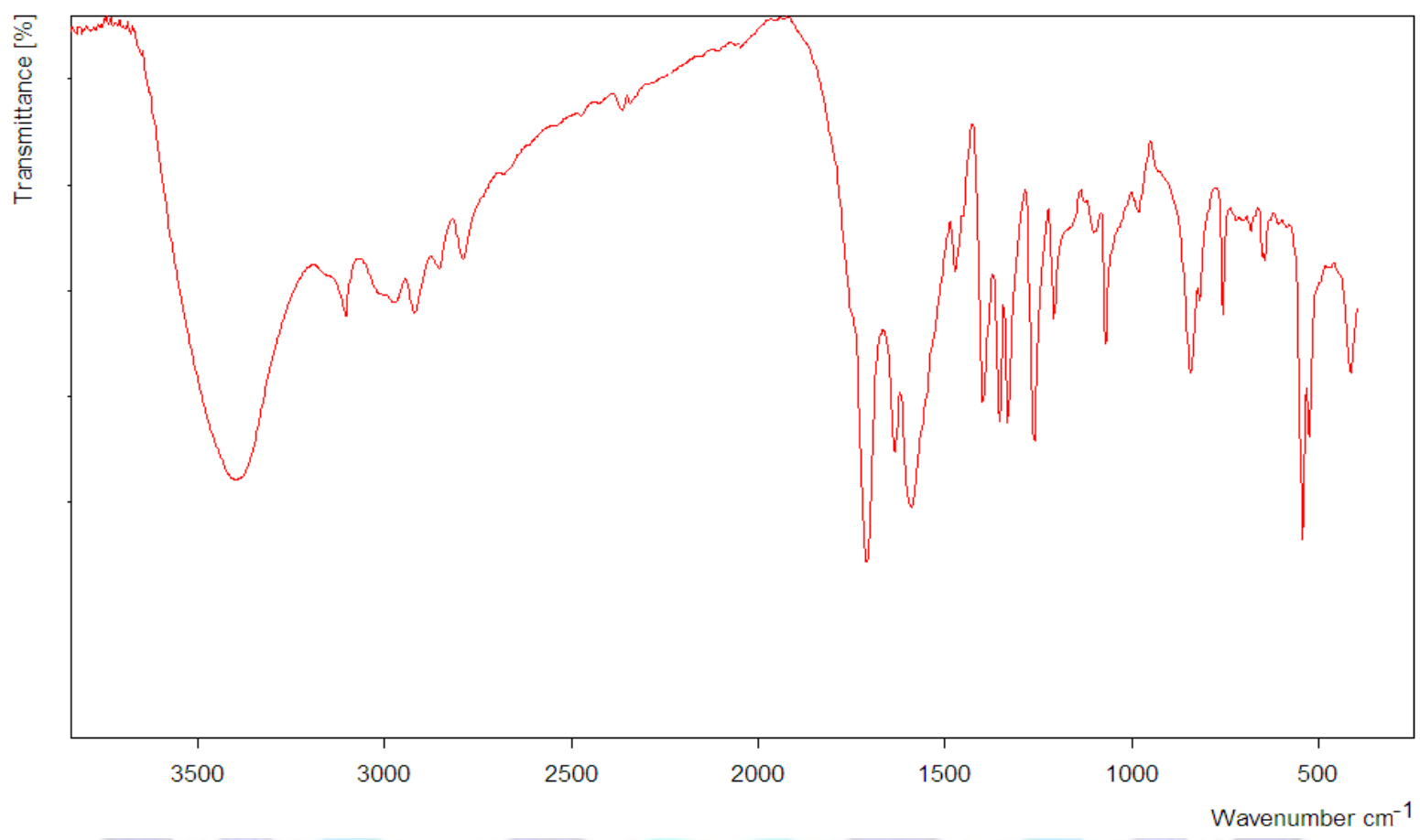

Fig. 1: Infrared spectrum of [VO(HL)2].2H2O complex

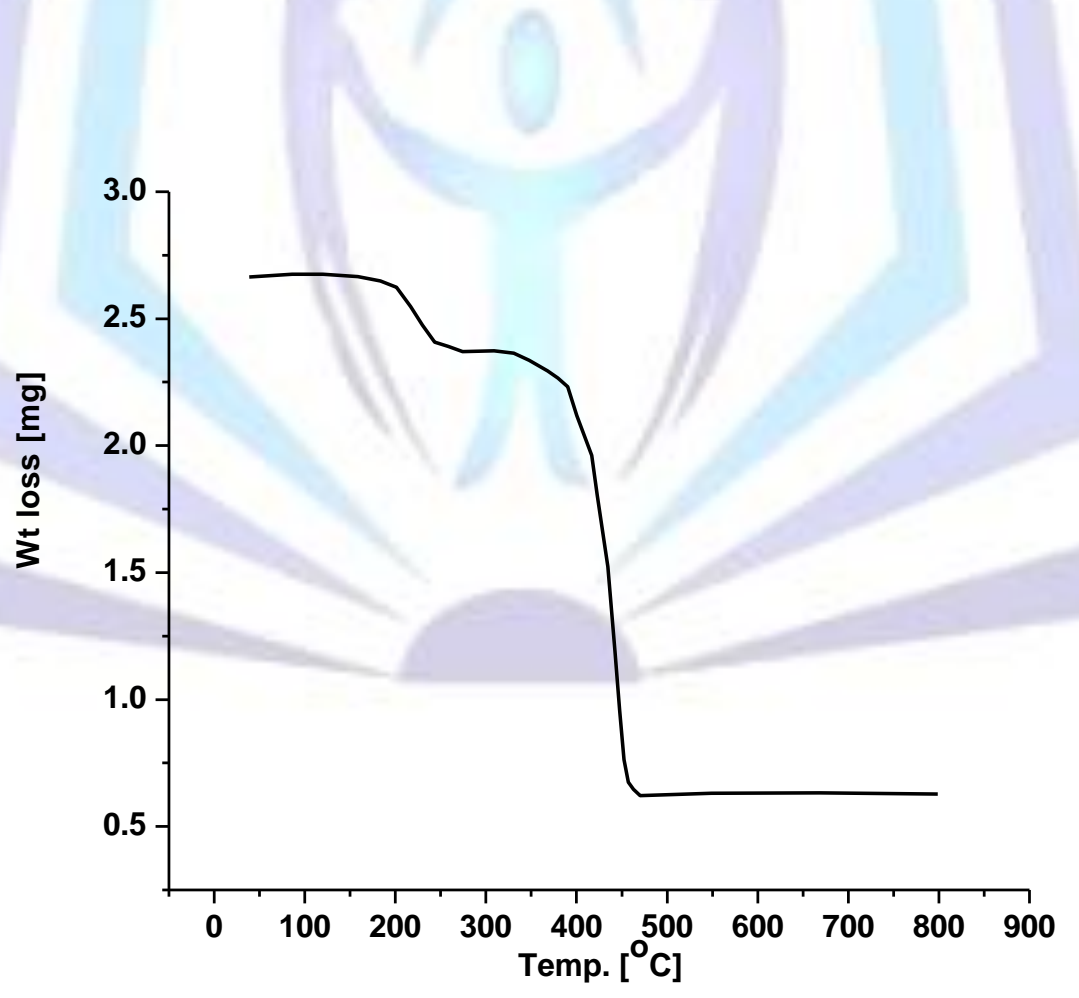

Fig. 2: TGA curve of [VO(HL)2].2H2O complex 